logos_i_ethos_2019_2_(50), s. 67-86

DOI: http://dx.doi.org/10.15633/lie.3478

Sławomir Drelich

https://orcid.org/0000-0003-0620-893X

Uniwersytet Mikołaja Kopernika w Toruniu

\title{
Podstawy aksjologii politycznej III RP na podstawie konstytucji z 2 kwietnia 1997 roku
}

\section{Aksjotwórczy charakter ustawy zasadniczej - wprowadzenie}

Konstytucja jest szczególnym aktem normatywnym, który reguluje podstawy ustrojowe współczesnego państwa, organizuje i strukturyzuje dr Sławomir Drelich - politolog i etyk, adiunkt na Wydziale Politologii i Studiów Międzynarodowych UMK w Toruniu; zajmuje się myślą polityczną (liberalizm, populizm, libertarianizm), komunikacją społeczną i dyskursem publicznym; autor książek: Populistów ethos zmanipulowany (Torun 2010) i Wojny trybuna ludowego. Przypadek Andrzeja Leppera (Toruń 2013).

działające w nim naczelne organy władzy publicznej, a ponadto precyzuje i gwarantuje wymienione w specjalnym katalogu wolności i prawa człowieka i obywatela. Tak jest w aktualnie obowiązującej polskiej ustawie zasadniczej, podobnie zresztą jak w innych pisanych konstytucjach państw współczesnego świata. Wskazuje się również, że te szczególne akty normatywne powinny spełniać także funkcję polityczną, ideologiczną oraz symboliczną, ale ponadto - jak wyjaśnia Leszek Garlicki, a co ma szczególne znaczenie z punktu widzenia rozważań podjętych w niniejszym tekście - „współczesne konstytucje traktować się powinno jako zobiektywizowany wyraz pewnego systemu wartości - podstawowych dla funkcjonowania całego państwa i społeczeństwa"1. Paweł Sarnecki podkreśla dobitnie, że każda „konstytucja to nie tylko bilans (rozumiany jako podsumowanie przeszłości), lecz również wytyczenie drogi 
na przyszłość" ${ }^{2}$. Nie można zatem interpretować ustawy zasadniczej wyłącznie jako ram prawno-instytucjonalnych dla zastanej rzeczywistości politycznej, społecznej i gospodarczej, ale zawsze należy postrzegać ją również jako sui generis model, który ustawodawca pragnąłby ukształtować, a który wynika z pewnego katalogu wartości i idei o charakterze fundamentalnym dla danego ustroju. Trzeba jednak pamiętać, że nie należy „utożsamiać pojęciowo prawa i moralności, jak też niebezpiecznym przedsięwzięciem jest narzucanie określonych norm moralnych poprzez przymus prawny"3. Konstytucja powinna zatem zawierać pewien katalog wartości, stanowiących finalnie swoistą aksjologię polityczną państwa, jednakże katalog ów powinien mieć charakter na tyle ogólny i powszechnie akceptowalny, aby nie rodził sporów, kłótni czy też konfliktów.

Marian Kallas - próbując właśnie scharakteryzować ów fundamentalny katalog wartości wpisany w tekst polskiej ustawy zasadniczej wskazuje, że konstytucja z 2 kwietnia 1997 roku „opiera się na pluralizmie aksjologicznym”4 . Jego zdaniem ów system wartości nie jest w pełni ukształtowany w samym tekście ustawy zasadniczej, zaś swoją ostateczną formę uzyska dopiero sumarycznie z całością ustawodawstwa konstytucyjnego ${ }^{5}$. Tomasz W. Szklarski podkreśla, że preambuła konstytucji może być właściwym miejscem, w którym „nakreśla się kierunki przyjmowane zazwyczaj w ustawach zasadniczych oraz wartości, jakimi kieruje się prawodawca”6 . Aleksandra Kustra dodaje, iż „aksjologicznym założeniem każdej konstytucji jest [...] najwyższa wartość zawartych w niej postanowień, co z kolei nakazuje nadanie im najwyższej mocy prawnej i zapewnienia ich realizacji" ${ }^{7}$. Tak więc z jednej strony podstawowe regulacje ustrojowe czy też konstrukcja instytucjonalna najważniejszych

2 P. Sarnecki, Idee przewodnie Konstytucji Rzeczypospolitej Polskiej z 2 kwietnia 1997 r., „Przegląd Sejmowy" $1997 \mathrm{nr} 5$ (22), s. 11.

3 Z. Ziembiński, Wartości konstytucyjne: zarys problematyki, Warszawa 1993, s. 10.

${ }^{4}$ M. Kallas, Historia ustroju Polski X-XX w., Warszawa 2003, s. 544.

5 M. Kallas, Historia ustroju Polski X-XX w., dz. cyt., s. 544-545.

6 T. W. Szklarski, Wzorzec ustrojowy. Przyczynek do rozważań na temat recepcji w nauce o systemach politycznych, „Przegląd Sejmowy” 2016 nr 5 (136), s. 66.

7 A. Kustra, Współczesny paradygmat nadrzędności konstytucji, „Studia Iuridica Toruniensia” 4 (2008), s. 119. 
organów państwowych, z drugiej zaś - również fundamentalne wartości zwerbalizowane w ustawie zasadniczej, uzyskawszy rangę zapisów konstytucyjnych, zdobywają szczególną ochronę i pozycję w krajowym systemie prawnym. Celem zasadniczym niniejszego tekstu jest zatem zarysowanie podstawowego katalogu wartości wymienianych i zabezpieczanych w polskiej konstytucji z 1997 roku oraz przedstawienie ich jako zrębu swoistej aksjologii państwowej III Rzeczypospolitej. Celem będzie również wskazanie ewentualnych kontrowersji związanych z próbą hierarchizacji niniejszych wartości. Antoni Dudek, analizując niską frekwencję i wyniki referendum konstytucyjnego z 1997 roku, pesymistycznie konkludował, że „okazało się, że tylko około połowy Polaków jest w ogóle zainteresowanych sprawami publicznymi, a w dodatku są oni silnie podzieleni, reszta zaś nie wykazuje jakiegokolwiek zainteresowania kształtem ustrojowym państwa, w którym przyszło im żyć"s. Należy jednak pamiętać, że niezależnie od tego, ilu Polaków głosowało w 1997 roku za przyjęciem konstytucji, to zgodnie z przyjętą procedurą została ona przez naród przyjęta i stała się nadrzędnym wobec pozostałych aktem normatywnym.

\section{Nadrzędność prawna i nadrzędność aksjologiczna}

Legalnie uchwalona i przyjęta przez naród konstytucja stała się tzw. prawem nadrzędnym. Taki jej charakter sprawia, że wszystkie inne akty normatywne muszą być $\mathrm{z}$ konstytucją zgodne - zresztą w konstytucji z 1997 roku przewidziano odpowiednie instrumenty badania konstytucyjności ustaw i innych aktów normatywnych przez Trybunał Konstytucyjny. Kustra zaznacza, że „«nadrzędność» jest pewnym ukształtowanym paradygmatem współczesnej kultury konstytucyjnej rozumianym jako

8 Dudek wskazuje, że polska ustawa zasadnicza została przyjęta de facto niewielką przewagą głosujących. Za jej przyjęciem opowiedziało się ledwie 52,71\% głosujących, co stanowi niespełna 6,4 mln Polaków. Oczywiście z punktu widzenia formalnego taka większość wystarczała do jej wejścia w życie, jednakże z punktu widzenia rangi i znaczenia tego aktu normatywnego niestety ujmowało to jej roli prawa konsolidującego wspólnotę polityczną. Zob. A. Dudek, Historia polityczna Polski 1989-2005, Kraków 2007, s. 340. 
zbiór podstawowych pojęć, twierdzeń, koncepcji i przekonań, cechujących się pewną spójnością logiczną i pojęciową". Podkreśla również, że „w teorii prawa konstytucyjnego nadrzędność uznaje się za oczywisty skutek, racjonalny wynik roli aktu konstytucyjnego [...] czy szerzej ogółu norm konstytucyjnych $[\ldots]$ w hierarchicznie uporządkowanym systemie prawa"10. Nadanie konstytucyjnej rangi pewnym normom, ale przecież również wartościom, sprawia, że uzyskują one nie tylko szczególne miejsce w hierarchii norm i aktów normatywnych, lecz także szczególną ochronę. Jak bowiem wskazuje Ryszard M. Małajny, „władza państwowa może zniszczyć wartości, do ochrony których została ustanowiona"11 w każdym razie zawsze należy wziąć pod uwagę taką ewentualność. Ze względu na takie założenie „normy konstytucyjne w zdecydowanej większości nie są tzw. leges imperfectae, tj. regulacjami pozbawionymi sankcji. Naruszenie postanowień konstytucji, tak jak każdej innej ustawy, skutkuje wywołaniem szeregu negatywnych konsekwencji prawnych skierowanych z zasady do podmiotu dopuszczającego się naruszenia" ${ }^{12}$. Jeśli jednak mówimy o naruszaniu pewnych norm prawnych - także o charakterze deliktu konstytucyjnego - to powinniśmy pamiętać, że odpowiednie ustawodawstwo krajowe zwykle przewiduje określone sankcje i sposoby ścigania osób normy te naruszających. Sprawa jednak wydaje się dużo bardziej skomplikowana, kiedy mówimy o naruszaniu fundamentalnych wartości zarysowanych w ustawie zasadniczej.

Ewentualne zastosowanie sankcji względem osób naruszających fundamentalne wartości zarysowane w konstytucji byłoby możliwe wyłącznie w sytuacji swoistej spójności aksjologicznej. Zygmunt Ziembiński wskazuje, że ze spójnością aksjologiczną mamy do czynienia wówczas, gdy „normy danego systemu prawnego znajdują uzasadnienie aksjologiczne $[. .$.$] w odpowiednio uporządkowanym systemie wartości, którym$

9 A. Kustra, Współczesny paradygmat nadrzędności konstytucji, dz. cyt., s. 127.

10 A. Kustra, Współczesny paradygmat nadrzędności konstytucji, dz. cyt., s. 105.

11 R. M. Małajny, Podział władzy państwowej jako przesłanka jej legitymacji, „Przegląd Sejmowy” 2014 nr 3 (122), s. 27.

12 M. Dąbrowski, Sankcje konstytucyjne. Istota, funkcje oraz rodzaje, „Przegląd Sejmowy” 2014 nr 5 (124), s. 10. 
realizacja norm ma służyć" ${ }^{13}$. Jeszcze precyzyjniej spójność aksjologiczną charakteryzuje Marek Piechowiak:

Spójność aksjologiczna możliwa jest wówczas, gdy wartości, których realizacji mają służyć normy konstytucji, są uporządkowane na tyle, aby móc rozstrzygać przypadki, w których dochodzi do kolizji między poszczególnymi, określonymi in abstracto, wchodzącymi w grę wartościami, gdy realizacja jednej wartości nieuchronnie powiązana jest $\mathrm{z}$ ograniczeniem możliwości realizacji innej ${ }^{14}$.

Niewątpliwie spójność aksjologiczna powinna być finalnym produktem zapisów ustawy zasadniczej, ale jednocześnie taka spójna aksjologicznie konstrukcja winna minimalizować możliwość zajścia poważnych konfliktów o wartości. Konflikty o wartości bowiem, choć niekoniecznie muszą skutkować nieefektywnością czy niewydolnością systemu politycznego $\mathrm{w}$ jego wymiarze instytucjonalnym, mogą jednakowoż stawać się zarzewiem konfliktów społecznych czy też braku konsensusu między wpływowymi grupami interesów w sprawach fundamentalnych dla wspólnoty politycznej. Ponadto nadrzędność aksjologiczną należałoby rozumieć jako swego rodzaju - by użyć określenia Monteskiuszowskiego - „ducha praw”, czyli aksjologiczne ramy ustroju. Owe fundamentalne zasady filozof ten określa mianem loix fondamentales, czyli „zasadniczymi prawami” - one właśnie „wypływają wprost z natury" danego ustroju, ale jednocześnie przecież określają jego natu$\mathrm{rę}^{15}$. Dostrzegł to Gustaw Radbruch, dokonując po II wojnie światowej rewizji stanowiska pozytywistycznego w nauce prawa, kiedy wskazał, że ,jedynie miarą prawa ponadustawowego możemy określać, czym jest prawo, bez względu na to, czy to prawo ponad wszelkimi ustawami nazwiemy prawem natury, prawem boskim czy prawem rozumu"16. Jak

13 Z. Ziembiński, Wartości konstytucyjne: zarys problematyki, Warszawa 1993, s. 7.

${ }_{14}$ M. Piechowiak, W sprawie aksjologicznej spójności Konstytucji RP. Dobro wspólne czy godność człowieka?, w: Jednolitość aksjologiczna systemu prawa w rozwijających się państwach demokratycznych Europy, red. S. L. Stadniczeńko, Opole 2011, s. 111.

15 Monteskiusz, O duchu praw, przeł. T. Boy-Żeleński, Warszawa 2002, s. 22.

16 G. Radbruch, Ustawa i prawo, przeł. J. Zajadło, „Ius et Lex” 2002 nr 1, s. 160. 
więc widać, wartości zdają się być sprawą fundamentalną dla kształtu wspólnoty politycznej, choć oczywiście - trzeba się zgodzić z Jarosławem Szymankiem - „ustawa zasadnicza [...], aby stanowiła lex w pełnym tego słowa znaczeniu musi być aktem «odpowiadającym chwili», tzn. aktem pragmatycznym, prakseologicznym i użytecznym, co $a$ priori oznacza również, że zamienialnym, dostosowanym do odpowiedniego kontekstu sytuacyjnego, w jakim przychodzi mu funkcjonować" ${ }^{17}$. Choć oczekiwać trzeba, aby ustawa zasadnicza była jak najbardziej dostosowana do zastanych realiów politycznych, społecznych czy też kulturowych, to jednak trudno wyobrazić sobie, aby nie zawierała swoistej podstawy aksjologicznej, na której mógłby stanąć ustrój - rozumiany jednakże w duchu klasycznym, nie zaś wyłącznie jako system polityczny. Ustrój, który - wedle słów Leo Straussa - „jest porządkiem, formą, która nadaje społeczeństwu jego charakter. [...] oznacza zarazem formę życia społeczeństwa, styl życia, zmysł moralny, typ społeczeństwa, typ państwa, typ rządu, ducha praw"18. To zaś jest zawsze wypadkową fundamentalnych wartości, szkieletu aksjologicznego wspólnoty politycznej.

\section{Katalog wartości III RP}

Charakterystykę aksjologicznego szkieletu polskiej konstytucji należy zacząć od preambuły, która stanowi nie tylko uroczysty wstęp, lecz także fundament wartości wymienianych w dalszej - normatywnej - części ustawy zasadniczej. Nie należy bagatelizować znaczenia preambuły, co potwierdza fakt, iż była i jest ona punktem odniesienia w wielu sprawach rozstrzyganych przez Trybunał Konstytucyjny. Jerzy Oniszczuk wskazuje, że organ ten wielokrotnie odwoływał się do zapisów preambuły w celu „ustalenia wartości systemu prawnego, na którym został ten

17 J. Szymanek, Interpretacja przepisów wyznaniowych w konstytucji, „Studia z Prawa Wyznaniowego" 9 (2006), s. 102.

18 L. Strauss, Czym jest filozofia polityki?, w: L. Strauss, Sokratejskie pytania, przeł. P. Maciejko, Warszawa 1998, s. 85. 
system zbudowany"19. Małgorzata Stefaniuk podkreśla, że w postępowaniach przed Trybunałem Konstytucyjnym na preambułę powoływali się wnioskodawcy, sam Trybunał w swoich orzeczeniach, ale również inni uczestnicy postępowań, jak np. prokurator generalny. Jej zdaniem potwierdza to fakt, że „doceniono rolę preambuły jako istotnego elementu wzmacniającego siłę argumentacji dla prezentowanego stanowiska"20. Katalog wartości, na jakie się powoływano w odniesieniach do roty preambuły, jest dość szeroki. Stefaniuk wskazuje, że najczęściej powoływano się na zasadę pomocniczości, jednak również na inne zasady: dialogu społecznego, sprawiedliwości, wolności, współdziałania, rzetelności i sprawności działania instytucji publicznych, współpracy z wszystkimi krajami dla dobra rodziny ludzkiej. W uzasadnieniach wielu orzeczeń co również zauważa Stefaniuk - powoływano się także na zapis o czasach, "gdy podstawowe wolności i prawa człowieka były w naszej Ojczyźnie łamane"21. Oprócz tych - zajmujących najwięcej miejsca w refleksjach sędziów Trybunału Konstytucyjnego - należy wymienić również wartości, jak: suwerenności zewnętrznej, demokracji, dobra wspólnego, równości, więzi i tradycji narodowych, poszanowania praw podstawowych, współdziałania władz, solidarności. Ustawodawcy dowartościowują również polskie doświadczenia historyczne i pragną, aby stały się one swoistym punktem odniesienia dla współczesnych.

Dalszy ciąg niniejszego fundamentu aksjologicznego zawiera pierwszy rozdział konstytucji zatytułowany: Rzeczpospolita. Wymieniono w nim następujące wartości: dobro wspólne, sprawiedliwość społeczna, suwerenność narodu, niepodległość, wolność oraz prawa człowieka i obywatela, bezpieczeństwo, dziedzictwo narodowe, środowisko,

19 J. Oniszczuk, Konstytucja Rzeczypospolitej Polskiej w orzecznictwie Trybunału Konstytucyjnego, Kraków 2000, s. 19. Cyt. za: M. Stefaniuk, Preambuła do Konstytucji RP z 2 kwietnia 1997 roku $w$ orzecznictwie Trybunału Konstytucyjnego, „Annales Universitatis Mariae Curie-Skłodowska. Sectio G” 50/51 (2003/2004), s. 203.

20 M. Stefaniuk, Preambuła do Konstytucji RP z 2 kwietnia 1997 roku w orzecznictwie Trybunału Konstytucyjnego, dz. cyt., s. 205.

${ }_{21}$ M. Stefaniuk, Preambuła do Konstytucji RP z 2 kwietnia 1997 roku w orzecznictwie Trybunału Konstytucyjnego, dz. cyt., s. 221. 
zrównoważony rozwój, kultura, tożsamość narodowa, pluralizm polityczny i społeczny, interes publiczny, małżeństwo, rodzina, macierzyństwo i rodzicielstwo, własność, praca, bezstronność światopoglądowa i filozoficzna. W ustawie zasadniczej nie określono expressis verbis, która z wymienionych zasad czy wartości powinna mieć charakter prymarny ani czy w ogóle można w jakiś sposób hierarchizować wymieniane wartości. Sam fakt, że w akcie normatywnym dużo miejsca poświęcono zasadom ustrojowym skłania Garlickiego do wniosku, iż konstytucja Z 1997 roku jest „w wielu miejscach «przegadana» i za mało jurydyczna. Takie ujęcie jej tekstu pozostawia doktrynie znaczną swobodę w ustalaniu katalogu zasad ustroju Rzeczypospolitej Polskiej"22. Rozumienie i interpretacja wartości, jakie zamieszczono w ustawie zasadniczej, stają się niejednokrotnie nie lada wyzwaniem. Już wymieniane w pierwszym artykule „dobro wspólne” może przecież być interpretowane niezwykle szeroko, a jego interpretacja może się różnić w przypadku dokonywania jej przez przedstawicieli różnych środowisk politycznych czy zwolenników poszczególnych ideologii politycznych. Andrzej Szahaj uważa, że cały „problem jedynie w tym, w jaki sposób owo dobro zdefiniujemy i kto będzie miał prawo określać, czym ono jest, albowiem dobro to nie jest wcale czymś samo-przez-się-zrozumiałym. Demokracja liberalna, przynajmniej nominalnie, pozwala każdemu brać udział w definiowaniu i interpretowaniu dobra wspólnego" ${ }^{23}$. Piechowiak podkreśla, że „dobro wspólne to suma warunków życia społecznego umożliwiających i ułatwiających integralny rozwój wszystkich członków wspólnoty politycznej i tworzonych przez nich społeczności" ${ }^{24}$. W tym samym duchu wartość tę wyjaśnia Marek Zubik, który wskazuje, że „przez «dobro wspólne» należałoby rozumieć sumę wszystkich instytucji i warunków, umożliwiających jednostkom i ich grupom osiągnięcie pełnego

22 L. Garlicki, Polskie prawo konstytucyjne. Zarys wykładu, Warszawa 1998, s. 52.

23 A. Szahaj, Jednostka czy wspólnota? Spór liberałów z komunitarystami a "sprawa polska”, Warszawa 2000, s. 259.

${ }^{24}$ M. Piechowiak, Dobro wspólne jako fundament polskiego porządku konstytucyjnego, Warszawa 2012, s. 433. 
rozwoju”25. Władysław Jóźwicki interpretuje „dobro wspólne” w podobnym duchu, a mianowicie jako „zapewnienie służebnego względem jednostki charakteru państwa i jego instytucji” ${ }^{26}$. Zdaje się, że jest to chyba najbardziej niekontrowersyjne i neutralne - choć oczywiście niezwykle ogólne - rozumienie tejże wartości. Jóźwicki z przytoczonych definicji wysnuwa wniosek na temat służebnej roli państwa i jego organów wobec obywateli - dopiero wówczas rzeczywiście można będzie widzieć w państwie „dobro wspólne” wszystkich obywateli ${ }^{27}$. Podobne wątpliwości czy też kontrowersje mogą budzić jeszcze dwie wartości wymieniane w pierwszym rozdziale polskiej konstytucji, mianowicie zrównoważony rozwój oraz interes publiczny. Pewnie ich sposób rozumienia również może wynikać $\mathrm{z}$ ideowych bądź ideologicznych źródeł, stąd są to wartości poddające się dość szerokiej interpretacji.

Niektórzy myśliciele zdają się sugerować, że również pewne rozwiązania instytucjonalne należałoby traktować jako wartości. Najczęściej proponuje się taką aksjologiczną interpretację w odniesieniu do zasad: demokracji, państwa prawa, podziału i równowagi władz, decentralizacji władzy publicznej, samorządności, społecznej gospodarki rynkowej, a także wolności działalności gospodarczej. Wszystkie te instytucje będą niewątpliwie traktowane jako wartości sui generis, jeśli przyjąć, że model państwa liberalnego - bo przecież w istocie są one tego modelu ucieleśnieniem - jest modelem godnym obrony i dążenia. William Galston wskazuje, że jednym ze sposobów uzasadniania wartości samego państwa liberalnego - z całością jego instytucji - jest udowadnianie, że „państwo liberalne jest godne akceptacji nie dlatego, że promuje pewien styl życia, ale właśnie dlatego, że jako jedyne tego nie czyni”28. Ponieważ

25 M. Zubik, Refleksje nad „dobrem wspólnym” jako pojęciem konstytucyjnym, w: Prawo a polityka, red. M. Zubik, Warszawa 2007, s. 404.

26 W. Jóźwicki, Rzeczpospolita dobrem wspólnym wszystkich obywateli jako uzasadnienie wymogu wierności obywateli wobec niej w kontekście integracji europejskiej, w: Konstytucja Rzeczypospolitej Polskiej w pierwszych dekadach XXI wieku wobec wyzwań politycznych, gospodarczych, technologicznych i społecznych, red. S. Biernat, Warszawa 2013, s. 24.

27 W. Jóźwicki, Rzeczpospolita dobrem wspólnym wszystkich obywateli jako uzasadnienie wymogu wierności obywateli wobec niej w kontekście integracji europejskiej, dz. cyt., s. 12.

28 W. Galston, Cele liberalizmu, przeł. A. Pawelec, Kraków-Warszawa 1999, s. 98. 
więc wymienione narzędzia instytucjonalne - od demokracji proceduralnej i państwa prawa, aż po samorządność i podział władz - mają gwarantować neutralność państwa, można by uznawać je za nie tylko instytucje, lecz również swoiste liberalnie rozumiane wartości. Paweł Śpiewak przekonuje, że ,idee demokracji, praw człowieka i, do pewnego stopnia, konstytucjonalizmu, stały się swoistym moralnym esperanto całego świata” ${ }^{29}$. Owe „moralne esperanto” należy interpretować właśnie jako „aksjologiczne minimum”, na którym winno się opierać istnienie państwa w liberalno-demokratycznej tradycji Zachodu, ta zaś stała się już przecież wzorcem niemalże powszechnie akceptowalnym, a deklaratywnie typem idealnym dążeń wielu rozwiązań ustrojowych. Małajny przywołując poglądy Johna Locke’a, Monteskiusza, a w szczególności amerykańskich „ojców konstytucji” (the Founding Fathers, the Framers) wskazuje wręcz, że spośród wymienionych powyżej instrumentów instytucjonalno-proceduralnych wartością fundamentalną jest idea podziału i równowagi władz, która staje się de facto „,aksjomatem wszelkiej wiedzy ustrojowej" ${ }^{30}$. W podobnym duchu na zagadnienie to spogląda Bruce Ackerman, dla którego wolność i rządy prawa stanowią „niepodważalne wartości”31. Małajny jednakowoż zachęca do przyjmowania postawy sceptycyzmu czy też przynajmniej pewnego dystansu w kwestii rozważania aksjologicznych fundamentów ustrojów państwowych. Taki dystans i sceptycyzm prezentuje on w swoich konkluzjach dotyczących zasady trójpodziału władzy. Dowodzi, że „idea ta nie jest «wiekuistym prawem» czy "przenajświętszym dogmatem teorii i praktyki konstytucyjnej», ale bez wątpienia również nie «absurdem» czy «próżną formułą». Dlatego nie sposób zgodzić się z ortodoksyjnymi adherentami analizowanej przez nas idei, którzy ją absolutyzują"32. Przez jednych zatem przywołane instytucje współczesnych państw liberalno-demokratycznych będą interpretowane jako wartości, przez innych - jako jedynie proceduralne

29 P. Śpiewak, Obietnice demokracji, Warszawa 2004, s. 15.

30 R. M. Małajny, Podział władzy państwowej jako przesłanka jej legitymacji, dz. cyt., s. 17.

31 B. Ackerman, Przyszłość rewolucji liberalnej, przeł. H. Grzegołowska-Klarkowska, Warszawa 1996, s. 72.

32 R. M. Małajny, Podział władzy państwowej jako przesłanka jej legitymacji, dz. cyt., s. 28. 
rozwiązania ustrojowe, sprawdzające się w praktyce, zabezpieczające podstawowe wolności i prawa osobiste oraz obywatelskie.

\section{W poszukiwaniu „zasady zasad”}

Ewentualny spór o katalog fundamentalnych wartości konstytucyjnych III Rzeczypospolitej może dotyczyć z jednej strony - samej zawartości niniejszego katalogu, $\mathrm{z}$ drugiej zaś - interpretacji wymienionych wartości. Ów aksjologiczny trzon - jak już wspomniano powyżej - może wyglądać inaczej, jeśli zdamy sobie sprawę, że także zapisy ustawy zasadniczej mogą podlegać wykładni, a także interpretacji na poziomie filozoficznym, politologicznym czy politycznym. Zastanawiające w tym kontekście wydaje się również to, czy na bazie zapisów polskiej konstytucji i katalogu wartości w niej wymienianych jesteśmy w stanie wyłonić jedną, której nadalibyśmy rangę „zasady zasad”. Rozumieć ją należy jako "taką normę konstytucyjną, z której wynika grupa innych norm konstytucyjnych”"33. Tomasz Słomka podkreśla, że „tożsamość systemu politycznego państwa określają i opisują fundamentalne zasady konstytucyjne, do których zaliczyć należy przede wszystkim zasadę państwa jako dobra wspólnego i zasadę demokratycznego państwa prawnego" ${ }^{34}$. Kustra przekonuje, że kwestia „zasady zasad” budzi w doktrynie prawa konstytucyjnego wiele kontrowersji, albowiem teoretycy i konstytucjonaliści wskazują albo na zasadę państwa prawa, albo na zasadę suwerenności narodu jako przykłady właśnie takowej „zasady zasad”, czyli właśnie wartości fundamentalnej ${ }^{35}$. Słomka przekonuje, że „zasada demokratycznego państwa prawnego winna być traktowana jako swoista megazasada («matka» innych zasad) ustrojowa, stanowiąca «kręgosłup» funkcjonowania systemu politycznego współczesnej Polski”36. Z kolei Bartłomiej Nowotarski podkreśla fundamentalną rolę zasady

33 A. Kustra, Wspótczesny paradygmat nadrzędności konstytucji, dz. cyt., s. 116.

34 T. Słomka, System polityczny i konstytucyjny Rzeczypospolitej Polskiej, s. 15, http://biblioteka. oapuw.pl/tomasz-slomka-system-polityczny-i-konstytucyjny-rzeczypospolitej-polskiej/ (3.01.2018).

35 Zob. A. Kustra, Współczesny paradygmat nadrzędności konstytucji, dz. cyt., s. 116-117.

36 T. Słomka, System polityczny i konstytucyjny Rzeczypospolitej Polskiej, dz. cyt., s. 15. 
suwerenności, wskazując, iż „tym, co m.in. odróżnia dobrze funkcjonującą demokrację od innych niedemokratycznych form, jest odpowiedzialność władzy przed społeczeństwem jako suwerenem" ${ }^{37}$. Refleksję nad zdefiniowaniem owej wartości fundamentalnej i naczelnej, czyli właśnie „zasady zasad”, zdominowały te dwa środowiska. Kierunek przyjmujący dominację zasady państwa prawa należy niewątpliwie utożsamiać z nurtami liberalno-demokratycznymi oraz w pewnym stopniu $\mathrm{z}$ lewicowymi, natomiast w środowiskach narodowych, ale także populistycznych będzie dominować wykładnia suwerennościowa, odwołująca się częściej do demokracji bezpośredniej aniżeli u liberalnych demokratów.

Udzielenie jednoznacznej odpowiedzi na pytanie o „zasadę zasad” wyznaczoną zapisami polskiej konstytucji nie jest bynajmniej zadaniem łatwym. Co prawda, idea państwa prawa zaprezentowana została w art. 2 ustawy zasadniczej, zaś suwerenności narodu - dopiero $\mathrm{w}$ art. 4, jednakże nie można zapominać o tym, że w art. 1 zawarto ideę dobra wspólnego, w oparciu o którą „na czoło wysuwa się konstruowanie państwa «służebnego» wobec zamieszkujących je ludzi, a zwłaszcza, choć dalece nie wyłącznie, wobec jego obywateli"38. To z kolei pozwala w większym stopniu wiązać ów art. 1 z zasadą suwerenności aniżeli praworządności. Podobnie jeśli raz jeszcze sięgnąć do preambuły Konstytucji Rzeczypospolitej Polskiej, wówczas okaże się, że została ona sformułowana w postaci woli werbalizowanej bezpośrednio przez suwerena: „my, Naród Polski - wszyscy obywatele Rzeczypospolitej [...] ustanawiamy Konstytucję Rzeczypospolitej Polskiej jako prawa podstawowe dla państwa”. Sarnecki wskazuje, że właśnie suwerenność narodu powinna być potraktowana jako pierwsza i naczelna zasada wyznaczona zapisami konstytucji z 1997 roku, jednakże dodaje on również, iż jako drugą naczelną ideę konstytucyjną powinno się wskazywać ideę

37 B. Nowotarski, Kryzys zasady przedstawicielstwa a odpowiedzialność władzy w demokracji. Próba konceptualizacji, „Przegląd Sejmowy” 2014 nr 1 (120), s. 12.

38 P. Sarnecki, Idee przewodnie Konstytucji Rzeczypospolitej Polskiej z 2 kwietnia 1997 r., dz. cyt., s. 11. 
praworządności ${ }^{39}$. Antoni Dudek natomiast wymienia nie dwie, lecz trzy wartości fundamentalne: suwerenność narodu, nienaruszalność podstawowych praw i wolności obywatelskich oraz trójpodział władzy ${ }^{40}$. Jak widać, Dudek nie wspomina o zasadzie państwa prawa, choć jedynym artykułem z ustawy zasadniczej, który w całości cytuje w swojej Historii politycznej Polski, jest ów art. 2, gdzie idea demokratycznego państwa prawnego została sformułowana. Należy zdawać sobie sprawę, że niezależnie od tego, którą z obu najczęściej wymienianych przez konstytucjonalistów wartości przyjąć jako naczelną czy też fundamentalną, w obu przypadkach będą się pojawiać zagrożenia, wynikające ze swoistego „totalizmu” interpretacyjnego stosowanego względem tej z zasad, którą za naczelną uznamy. Bezkrytyczne przywiązanie do wartości suwerenności i przedkładanie jej ponad państwo prawa może skutkować przyzwoleniem dla dyktatury większości - «tyranii większości» czy tė̇ «tyranii zbiorowej», jak ją określał Alexis de Tocqueville ${ }^{41}$ - odbywającej się pod osłoną hasła woli narodu. Z drugiej zaś strony - równie bezkrytyczne przywiązanie do idei państwa prawa może prowadzić do „legalizowania niesprawiedliwości, legalnego czynienia niesprawiedliwości oraz sankcjonowania prawniczego relatywizmu i sytuacjonizmu" ${ }^{\text {. }}$. Może więc najbezpieczniej byłoby przyjąć, że obie wartości - zarówno suwerenność narodu, jak i idea państwa prawa - powinny stanowić sumarycznie „zasadę zasad” i należałoby zawiesić wszelkie spory, której z nich przyznać status naczelnej.

39 P. Sarnecki, Idee przewodnie Konstytucji Rzeczypospolitej Polskiej z 2 kwietnia 1997 r., dz. cyt., s. 16.

40 A. Dudek, Historia polityczna Polski 1989-2005, dz. cyt., s. 337.

41 J. Baszkiewicz, Wstęp, w: A. de Tocqueville, O demokracji w Ameryce, tłum. M. Król, Warszawa 1976, s. 12.

42 P. Tarasiewicz, Państwo prawa i suwerenność człowieka, w: Od sprawiedliwości do państwa prawa, red. S. Kowolik, Tarnowskie Góry 2012, s. 14. 


\section{Aksjologia nowej wspólnoty politycznej - podsumowanie}

Skoro zaprezentowano katalog wartości wymienianych w konstytucji III Rzeczypospolitej, wskazując równocześnie zarys dyskusji dotyczących rangi poszczególnych wartości oraz ewentualnego ich pierwszeństwa przed pozostałymi, należałoby jeszcze zastanowić się nad tym, czy rzeczywiście ów konstytucyjny katalog może stać się w rzeczywistości swoistym kodeksem całej wspólnoty politycznej. Wydaje się, że właśnie konstytucyjny katalog wartości musi stanowić - szczególnie dla nowo formowanej państwowości - swoisty aksjologiczny fundament, a zarazem gwarant możliwości realizacji dobra wspólnego. Owszem, III Rzeczpospolita uzyskała formę liberalnej demokracji, zaś nie wszyscy liberalni myśliciele zdają się werbalizować przywiązanie do idei dobra wspólnego. Szahaj udowadnia jednak, że błędna jest konkluzja, że liberałowie w ogóle ideę dobra wspólnego porzucają. Suwerenność ludu - jedna z wartości, które mogłyby stanowić trzon i swoistą „zasadę zasad” w polskiej aksjologii politycznej - zdaje się być odpowiedzią na pytanie o to, kto będzie miał prawo określać, czym jest to dobro wspólne. Niestety jednak - zgodnie z wnioskami Śpiewaka - „mitem jest obietnica suwerenności ludu. Ta obietnica została złamana na skutek rozrostu publicznych biurokracji. Biurokracje rozbudowują nieograniczony system zależności hierarchicznych i oligarchicznych, co stoi w jaskrawej sprzeczności z logiką demokracji”43. Szereg instrumentów demokracji liberalnej ma jednak stanowić dowód, że suweren-lud decyduje, a tym samym przynajmniej przekazuje legitymację do definiowania i realizowania dobra wspólnego politykom.

Natomiast zasada państwa prawa - kolejna $\mathrm{z}$ kandydatek do miana „zasady zasad” - stanowiłaby zabezpieczenie dla indywidualnych swobód, m.in. właśnie związanych $z$ dążeniem do realizacji wspomnianego dobra wspólnego czy też interesów partykularnych. Jak twierdzi Galston, „cechą wyróżniającą liberalizm nie jest brak materialnej koncepcji dobra, lecz opór wobec egzekwowania tej koncepcji w sferze publicznej

43 P. Śpiewak, Obietnice demokracji, Warszawa 2004, s. 166. 
za pomocą przymusu" ${ }^{44}$, dlatego właśnie tak duża rola idei praworządności, będącej przecież zabezpieczeniem przed ową przemocą. Prawo sprawia bowiem, że - jak pisał Frédéric Bastiat - „istnienie państwa odczuwać będziemy wyłącznie jako nieocenione dobrodziejstwo bez-

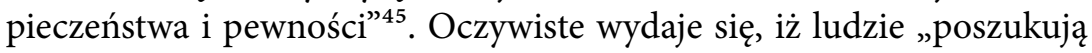
innych wartości i co innego jest dla nich dobrem. Przy czym owo co innego nie jest dobrem jedynie subiektywnym i rozumiemy jego atrakcyjność, nie wahamy się uznać go za dobro, nawet jeśli sami nie chcemy wieść żywota jemu właśnie poświęconego" ${ }^{\text {" }}$. Nie powinno więc dziwić, że katalog podstawowych wartości sformułowanych w polskiej ustawie zasadniczej z 1997 roku jest tak wąski i niezwykle wyważony. Ustawodawcy chodziło bowiem o stworzenie podstaw aksjologii politycznej, które spotkałyby się z - jeśli to możliwe - powszechną akceptacją, a tym samym o zbudowanie trwałych podstaw dla nowej formuły obywatelskości. A przecież - cytując Śpiewaka - „obywatelskość wymaga troski o coś więcej niż prywatny interes. Jeżeli nawet przeciętnego człowieka trudno zainteresować losem całego państwa, gdyż jest ono odległe i nadto potężne, na ogół łatwo przekonać go do podjęcia spraw o być może mniejszej skali, ale bardzo ważnych"47. Widać w tym katalogu wartości chęć odbudowania przez ustawodawcę zaufania obywatela do państwa, ale przede wszystkim wzbudzenia w nim poczucia odpowiedzialności za wspólnotę polityczną, tak przecież istotnego w państwie demokratycznym.

Nie jest wykluczone, że gdyby polską konstytucję pisano w 1989, 1990 czy nawet 1991 roku, kształt niniejszego katalogu aksjologicznego byłby zdecydowanie inny. Ustawa zasadnicza była pisana, kiedy rozmach transformacji był już historią, a samo hasło transformacji budziło raczej społeczne niezadowolenie czy wręcz sprzeciw aniżeli aprobatę. Ackerman ubolewa nad faktem, że w Polsce po 1989 roku nie udało się uchwalić rewolucyjnej konstytucji. Budowniczy III RP - jak twierdzi

44 W. Galston, Cele liberalizmu, dz. cyt., s. 107.

45 F. Bastiat, Prawo, przeł. P. Toboła-Pertkiewicz, Warszawa 2015, s. 11.

46 A. Szahaj, Jednostka czy wspólnota? Spór liberałów z komunitarystami a „sprawa polska”, dz. cyt., s. 258.

47 P. Śpiewak, Obietnice demokracji, dz. cyt., s. 163. 
ów amerykański prawnik i politolog - „zbyt krótko wytrwali w poczuciu wspólnego zadania, by w ogólnonarodowym referendum zdobyć poparcie milionów członków i sympatyków «Solidarności». Rewolucyjna jedność rozpadła się, ujawniając oślepiający popis indywidualnej małostkowości i intelektualnych ambicyjek" ${ }^{\prime 48}$. W istocie tak było, dlatego też większy wpływ na ostateczny kształt ustawy zasadniczej a tym samym jej aksjologicznego zrębu - miały środowiska związane z postkomunistyczną lewicą i laickimi środowiskami umiarkowanego centrum $^{49}$. Szczególnie burzliwe debaty toczyły się w sprawie ewentualnych zapisów dotyczących religii i relacji z Kościołem katolickim, rodziny i małżeństwa czy też wolności sumienia. Garlicki przypomina, że „tu kontrowersje przybierały chyba najostrzejszą formę, przekształcając się $\mathrm{w}$ dalszym toku prac konstytucyjnych w debatę nad aksjologiczną zawartością nowej Konstytucji”"50. Poszczególne zapisy konstytucji były również efektem postrzegania przez partie swoich interesów politycznych rzadziej wykazywano się długofalowym myśleniem i przyjmowaniem perspektywy wieloletniej, częściej wygrywały bieżące polityczne układy, gry, obawy i niejednokrotnie emocje. Na negatywnej ocenie niektórych zapisów ustawy zasadniczej zaciążył również fakt, że w kadencji 19931997, kiedy to toczyły się główne prace nad dokumentem i finalnie został on przez Zgromadzenie Narodowe uchwalony, ugrupowania prawicowe - ze względu na silne rozdrobnienie polityczne - były szczątkowo wręcz reprezentowane, stąd też ich postulaty nie miały szansy uzyskać jakiejkolwiek siły przebicia w komisji konstytucyjnej. Nie dziwi więc, że niektóre środowiska polityczne także dziś podnoszą kwestię rewizji

48 B. Ackerman, Przyszłość rewolucji liberalnej, przeł. H. Grzegołowska-Klarkowska, Warszawa 1996, s. 59.

49 Leszek Garlicki pisze wprost, że „zasługą nurtu umiarkowanego było zbudowanie na przełomie 1996 i 1997 roku porozumienia czterech ugrupowań parlamentarnych (PSL, SLD, UP i UW), co pozwoliło na uzyskanie większości dwóch trzecich zarówno w Komisji Konstytucyjnej, jak i w Zgromadzeniu Narodowym. Stało się jednak oczywiste, że tak skonstruowana „koalicja konstytucyjna” będzie silnie zwalczana przez opozycję pozaparlamentarną, zwłaszcza przez Akcję Wyborczą Solidarność i Ruch Odbudowy Polski, które tymczasem powstały" (L. Garlicki, Polskie prawo konstytucyjne. Zarys wykładu, Warszawa 1998, s. 26-27).

${ }^{50}$ L. Garlicki, Polskie prawo konstytucyjne. Zarys wykładu, dz. cyt., s. 26. 
konstytucji bądź napisania zupełnie nowej ustawy zasadniczej. Co ciekawe, jednym z najczęściej wysuwanych argumentów jest właśnie ów aksjologiczny kształt konstytucji z 1997 roku. Jeszcze ciekawszy zaś jest fakt, że to, co przez jednych wskazywane jest jako ogromny atut - ogólność, umiar i koncyliacyjność zapisów werbalizujących wartości, dla innych świadczy o słabym ugruntowaniu w narodowych tradycjach lub wręcz o jego braku.

\section{Bibliografia}

Ackerman B., Przyszłość rewolucji liberalnej, przeł. H. Grzegołowska-Klarkowska, Warszawa 1996.

Bastiat F., Prawo, przeł. P. Toboła-Pertkiewicz, Warszawa 2015.

Dąbrowski M., Sankcje konstytucyjne. Istota, funkcje oraz rodzaje, „Przegląd Sejmowy” 2014 nr 5 (124), s. 9-28.

Dudek A., Historia polityczna Polski 1989-2005, Kraków 2007.

Galston W., Cele liberalizmu, przeł. A. Pawelec, Kraków-Warszawa 1999.

Garlicki L., Polskie prawo konstytucyjne. Zarys wykładu, Warszawa 1998.

Jóźwicki W., Rzeczpospolita dobrem wspólnym wszystkich obywateli jako uzasadnienie wymogu wierności obywateli wobec niej w kontekście integracji europejskiej, w: Konstytucja Rzeczypospolitej Polskiej w pierwszych dekadach XXI wieku wobec wyzwań politycznych, gospodarczych, technologicznych i społecznych, red. S. Biernat, Warszawa 2013, s. 7-25. Kallas, Historia ustroju Polski X-XX w., Warszawa 2003.

Kustra A., Wspótczesny paradygmat nadrzędności konstytucji, „Studia Iuridica Toruniensia” 4 (2008), s. 105-127.

Małajny R. M., Podział władzy państwowej jako przesłanka jej legitymacji, „Przegląd Sejmowy" $2014 \mathrm{nr} 3$ (122), s. 9-28.

Monteskiusz, O duchu praw, przeł. T. Boy-Żeleński, Warszawa 2002.

Nowotarski B., Kryzys zasady przedstawicielstwa a odpowiedzialność władzy w demokracji. Próba konceptualizacji, „Przegląd Sejmowy” 2014 nr 1 (124), s. 11-28.

Oniszczuk J., Konstytucja Rzeczypospolitej Polskiej w orzecznictwie Trybunału Konstytucyjnego, Kraków 2000. 
Piechowiak M., Dobro wspólne jako fundament polskiego porzq̨dku konstytucyjnego, Warszawa 2012.

Piechowiak M., W sprawie aksjologicznej spójności Konstytucji RP. Dobro wspólne czy godność człowieka?, w: Jednolitość aksjologiczna systemu prawa w rozwijających się państwach demokratycznych Europy, red. S. L. Stadniczeńko, Opole 2011, s. 111-123.

Radbruch G., Ustawa i prawo, przeł. J. Zajadło, „Ius et Lex” 2002 nr 1, s. 159-163.

Sarnecki P., Idee przewodnie Konstytucji Rzeczypospolitej Polskiej z 2 kwietnia 1997 r., „Przegląd Sejmowy” 1997 nr 5 (22), s. 9-31.

Słomka T., System polityczny i konstytucyjny Rzeczypospolitej Polskiej, http://biblioteka.oapuw.pl/tomasz-slomka-system-polityczny-i-konstytucyjny-rzeczypospolitej-polskiej/(3.01.2018).

Stefaniuk M., Preambuła do Konstytucji RP z 2 kwietnia 1997 roku w orzecznictwie Trybunału Konstytucyjnego, „Annales Universitatis Mariae Curie-Skłodowska. Sectio G” 50/51 (2003/2004), s. 203-223.

Strauss L., Czym jest filozofia polityki?, w: L. Strauss, Sokratejskie pytania, przeł. P. Maciejko, Warszawa 1998, s. 61-106.

Szahaj A., Jednostka czy wspólnota? Spór liberałów z komunitarystami a „sprawa polska”, Warszawa 2000.

Szklarski T. W., Wzorzec ustrojowy. Przyczynek do rozważań na temat recepcji w nauce o systemach politycznych, „Przegląd Sejmowy” 2016 nr 5 (136), s. 61-80.

Szymanek J., Interpretacja przepisów wyznaniowych w konstytucji, „Studia z Prawa Wyznaniowego" 9 (2006), s. 101-132.

Śpiewak P., Obietnice demokracji, Warszawa 2004.

Tarasiewicz P., Państwo prawa i suwerenność człowieka, w: Od sprawiedliwości do państwa prawa, red. S. Kowolik, Tarnowskie Góry 2012, s. 11-20.

Tocqueville A. de, O demokracji w Ameryce, tłum. M. Król, Warszawa 1976.

Voegelin E., Arystoteles, przeł. M. J. Czarnecki, Warszawa 2011.

Ziembiński Z., Wartości konstytucyjne: zarys problematyki, Warszawa 1993.

Zubik M., Refleksje nad „dobrem wspólnym” jako pojęciem konstytucyjnym, w: Prawo a polityka, red. M. Zubik, Warszawa 2007, s. 385-403. 


\section{Abstrakt \\ Podstawy aksjologii politycznej III RP na podstawie konstytucji z 2 kwietnia 1997 roku}

W 1997 roku została uchwalona i przyjęta przez naród w referendum polska konstytucja. Zasadniczym celem niniejszego artykułu jest zaprezentowanie wymienionych w polskiej ustawie zasadniczej wartości oraz przedstawienie ich jako swoistego fundamentu aksjologii politycznej III RP. Autor wskazuje, że Konstytucja Rzeczypospolitej Polskiej z 1997 roku stanowi nie tylko nadrzędny akt normatywny w państwie, ale jest również bazą aksjologii politycznej, jaką definiuje się, tworząc każdą wspólnotę polityczną. Kluczowymi wartościami dla aksjologii ustanawianej w polskiej konstytucji są zasady suwerenności ludu i państwa prawa.

\section{Słowa kluczowe}

konstytucja, wartości, aksjologia polityczna, wspólnota polityczna, III RP

\section{Abstract \\ The Fundamentals of political axiology of the Third Polish Republic on the basis of the Constitution of 1997}

The Polish constitution was passed in 1997. In the same year, the nation adopted the constitution in a referendum. The main purpose of this article is to present the values mentioned in the Polish constitution and to present them as a specific foundation of political axiology of the Third Polish Republic. The author indicates that the constitution of the Republic of Poland of 1997 is not only the overarching normative act in the state, but it is also the basis of political axiology, which is defined by creating every political community. The key values in the axiology of the Polish constitution are the principle of sovereignty of the people and the rule of law.

\section{Keywords}

constitution, values, political axiology, political community, Third Polsish Republic 
